\title{
THE USE OF AN ANTAGONIST 5-HT2A/C FOR DEPRESSION AND MOTOR FUNCTION IN PARKINSON'S DISEASE
}

\author{
Antonio Luiz dos Santos Werneck', Ana Lucia Rosso², Maurice Borges Vincent ${ }^{3}$
}

\begin{abstract}
Objective: To test the ability of a $5 \mathrm{HT} 2 \mathrm{a} / \mathrm{c}$ (trazodone) antagonist, to improve depression and motor function in Parkinson's disease (PD). Method: Twenty PD patients with and without depression were randomly assigned to receive trazodone (group 1) or not (group 2). They were evaluated through UPDRS and Hamilton Depression Rating Scale (HAM-D). Results: For the UPDRS the mean score of group 2 was $33.1 \pm 19.7$ and $37.1 \pm 18.0$ at the end. For the group 1, the corresponding scores were $31.4 \pm 11.3$ and $25.9 \pm 13.7$. The variations in the MannWhitney test were 0.734 at the initial moment and 0.208 at the final moment. The variation in the comparison of the initial moment with the final moment was 0.005 providing statistical significance. For the HAM-D, the mean score went up 4 points in group 2, contrary to a 5.5 points decrease in group 1. Conclusion: Data analysis shows that this agent significantly improves depression, but the motor function improved only in the depressed patients. Because of the known anti-dopaminergic property of the 5-HT2c receptors, a possible approach for depression in PD could be the use of 5-HT2c antagonists, similarly to the use of atypical neuroleptics in case of psychotic symptoms.
\end{abstract}

KEY WORDS: trazodone, depression, Parkinson's disease phases of PD.

Uso de um antagonista 5-HT 2a/c na depressão e na função motora de pacientes com doença de Parkinson

Resumo - Objetivo: Avaliar a eficácia de um antagonista 5-HT2a/c (trazodona) na depressão e na função motora de pacientes com doença de Parkinson (DP). Método: Vinte pacientes com DP com e sem depressão foram randomizados e divididos em 2 grupos com e sem a trazodona (grupos 1 e 2). Foram avaliados pela escala UPDRS e a de depressão de Hamilton (EDH). Resultados: A média inicial do grupo 2 na UPDRS foi 33,1 $\pm 19,7$

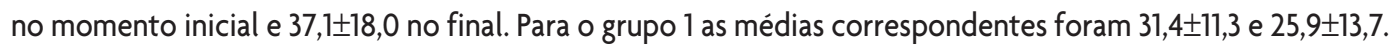
As variações no teste de Mann-Whitney foram 0,734 no momento inicial e de 0,208 no final. A variação na comparação entre o momento inicial e o final foi 0,005, caracterizando significância estatística. Para a EDH a média subiu 4 pontos no grupo 2, e desceu 5,5 pontos no grupo 1. Conclusão: A análise estatística revelou melhora da depressão, porém o benefício na função motora foi obtido apenas entre os deprimidos. Do mesmo modo que os neurolépticos atípicos atuam nos sintomas psicóticos, a ação secundária dopaminérgica do antagonista 5-HT2c pode ser útil no tratamento da depressão na DP.

PALAVRAS-CHAVE: trazodona, depressão, doença de Parkinson.

Non-motor symptoms make a significant contribution to the morbidity rates of Parkinson's disease (PD). Meta analytic data on the prevalence of depressive symptoms ranks to $31 \%$. Two previous series in Brazil found depression occurring in $38.33 \%$ and $24 \%$ of parkinsonian patients ${ }^{2,3}$. Surprisingly enough, the first studies on PD-related depression management date back to the end of the fifties, when Sigwald et al. ${ }^{4}$ related isolated cases of motor worsening during imipramine treatment in depressed patients with PD. Besides, out of 43 studies carried out during 35 years of research, there were only three randomized trials on this matter ${ }^{5}$. The leuchine-rich repeat kinase 2 (LRRK2) gene mutations are a common cause of familial and sporadic PD (PD). A research showed an association of

Hospital Universitário Clementino Fraga Filho da Universidade Federal do Rio de Janeiro (HUCCF/UFRJ), Rio de Janeiro RJ, Brazil: 'Professor de Neurologia da Universidade Estácio de Sá, Médico do Setor de Neurologia do HUCCF/UFRJ; ${ }^{2}$ Doutora em Neurologia (UFRJ), Médica do Setor de Neurologia do HUCFF/UFRJ; ${ }^{3}$ Doutor (Noruega), Professor Adjunto do Departamento de Clínica Médica (Serviço de Neurologia) do HUCCF/UFRJ.

Received 20 October 2008, received in final form 8 January 2009. Accepted 2 April 2009.

Dr. Antonio Luiz dos Santos Werneck - Rua México 70 / 902 - 20037-140 Rio de Janeiro RJ - Brasil. E-mail: antoniolluiz@yahoo.com.br 
the LRRK2 p.G2019S among Brazilian PD patients ${ }^{6}$. A possible susceptibility to develop depression in PD may be linked to a genetic condition. A recent animal model for PD showed that the engrailedl gene might be implicated in some cases of PD depressive patients?

Selective serotonin reuptake inhibitors (SSRIs) have been used to treat depression in PD. However, study evidence on the efficacy and safety of antidepressants in PD is lacking. There are several $5-\mathrm{HT}$ receptor subtypes, including the 5-HTla, 5-HTlb, 5-HT2a, 5-HT3 and 5-HT4 receptors. $5-\mathrm{HT} 2 \mathrm{c}$ receptors located to the substantia nigra and the ventral tegmental area may affect the dopaminergic activity, possibly interfering with motor control, motivation and rewarding mechanisms in the brain. In keeping with its ability to modulate dopamine (DA) neuron function in the brain, the $5-\mathrm{HT} 2 \mathrm{C}$ is currently considered as a major target for improved treatments of neuropsychiatric disorders related to DA neuron dysfunction, such as depression, schizophrenia, Parkinson's disease or drug addiction. It has been shown that the receptor 5-HT2a increases the dopaminergic activity, contrary to the reduced action evoked by the $5-\mathrm{HT} 2 \mathrm{c}$ receptor activation ${ }^{8}$. Despite these antagonistic actions, the much bigger anatomical, functional expressivity of 5-HT2c on 5-HT2a has become the inhibition of 5-HT2c as representative of the secondary dopaminergic function ${ }^{9,10}$.

The objective of this study was to test the hypothesis that oral trazodone, a 5-HT2a/c antagonist/reuptake inhibitor, improve motor phases and depression in PD.

\section{METHOD}

This randomized study was approved by the HUCFF-UFRJ ethics committee. Twenty PD patients classified in the category
3 (clinically definite: plastic rigidity, bradykinesia, postural disturbance and rest tremor) according to Calne et al." with and without depression were randomized in two groups. During 5 months (from T0 to T5), apart from usual PD care, group 1 (G1) received $50 \mathrm{mg}$ trazodone orally twice a day, contrary to group 2 (G2), with no trazodone. The individuals all came from the Movement Disorders Sector at the Clementino Fraga Filho University Hospital (Federal University of Rio de Janeiro).

All the individuals were blind examined every month by two examiners: one ranked the scales, without knowing if the drug was applied or not, and the other did the randomizing, not stratified, without knowing the categories of the scales. Subjects were examined every month and ranked by an independent physician according to different scales: Unified Parkinson's Disease Rating Scale Score (UPDRS), Hoehn and Yahr (HY), Schwab and England (SE) and the Hamilton Depression Rating Scale (HAM-D). The UPDRS was carried out for parts II and III. Depressive symptoms were assessed through the HAM-D 17 scale with a cut point of 10 (HAM-D $\geq 10)^{4}$. No other antiparkinsonian drug was added. Baseline exclusion criteria were: (1) secondary or atypical Parkinsonism; (2) organic mental syndrome related to cognitive and non-cognitive symptoms; (3) PD diagnosis before the age of 45 or after 75 . Follow-up exclusion criteria were: (1) change in the dose or type of the antiparkinsonian drug; (2) signs or symptoms potentially interfering with the results.

All the analysis was conducted in observed case type and in a comparison between groups. The p-values were two tailed. Wilcoxon test was used to compare different groups with baseline. The Mann-Whitney test was employed comparing the groups.

\section{RESULTS}

Fifteen men (75\%) and five women (25\%) entered the protocol. Ages ranged between 45 and 75 years old (av-

Table 1. UPDRS of groups with and without medication.

\begin{tabular}{|c|c|c|c|c|c|c|c|c|c|c|c|}
\hline \multicolumn{12}{|c|}{ Group without trazodone $(n=12)$} \\
\hline \multirow[b]{2}{*}{ Descriptive statistics } & \multicolumn{6}{|c|}{ UPDRS scores } & \multicolumn{5}{|c|}{ Baseline (t0) } \\
\hline & to & $\mathrm{t} 1$ & t2 & t3 & t4 & t5 & t1-t0 & t2-t0 & t3-t0 & t4-t0 & t5-t0 \\
\hline Average & 33.1 & 32.2 & 35.0 & 34.8 & 36.6 & 37.1 & -0.9 & 1.9 & 1.7 & 3.5 & 4.0 \\
\hline SD & 19.7 & 21.1 & 19.7 & 19.4 & 18.1 & 18.0 & 6.1 & 7.1 & 6.3 & 6.5 & 6.6 \\
\hline Medium & 29.5 & 25.0 & 30.5 & 31.10 & 33.0 & 34.5 & -12.0 & -11.0 & -8.0 & -6.0 & -6.0 \\
\hline \multicolumn{7}{|c|}{$\mathrm{p}$-value Wilcoxon test } & 0.552 & 0.390 & 0.458 & 0.121 & 0.071 \\
\hline \multicolumn{12}{|c|}{ Group with trazodone $(n=8)$} \\
\hline & \multicolumn{6}{|c|}{ UPDRS scores } & \multicolumn{5}{|c|}{ Initial evaluation (t0) } \\
\hline Descriptive statistics & to & $\mathrm{t} 1$ & t2 & t3 & t4 & t5 & t1-t0 & t2-t0 & t3-t0 & t4-t0 & t5-t0 \\
\hline Average & 31.4 & 29.4 & 30.6 & 28.1 & 27.1 & 25.9 & -2.0 & -0.8 & -3.3 & -4.3 & -5.5 \\
\hline SD & 11.3 & 12.0 & 10.3 & 11.9 & 12.8 & 13.7 & 3.0 & 6.3 & 8.0 & 5.5 & 5.3 \\
\hline Medium & 33.0 & 28.0 & 30.5 & 27.0 & 22.5 & 21.0 & -2.0 & -3.0 & -4.5 & -3.5 & -5.0 \\
\hline \multicolumn{7}{|c|}{$\mathrm{p}$-value Wilcoxon test } & 0.158 & 0.387 & 0.228 & 0.092 & 0.034 \\
\hline
\end{tabular}

UPDRS: Unified Parkinson's Disease Rating Scale Score; SD: standard deviation. 


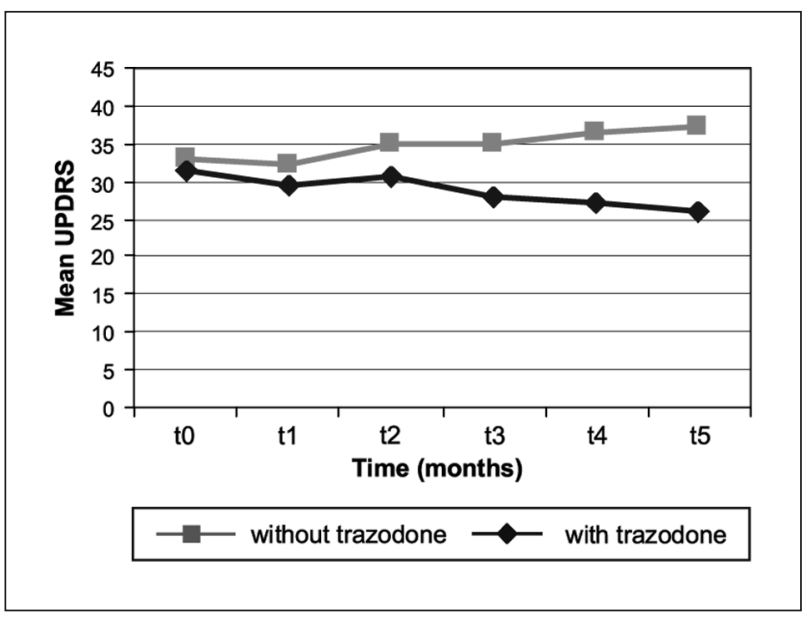

Figure. Mean UPDRS analysis in all patients.

erage 62.3). The length of the illness varied between 1.6 to 16.3 years. Randomization for the use of trazodone selected twelve patients without trazodone (G2) and eight with the drug (G1). The percentage of depressed patients in $\mathrm{G} 1$ was $75 \%(6 / 8)$ and $58,3 \%(7 / 12)$ in $\mathrm{G} 2$.

The scales of HY and SE provided an average and standard deviation without statistical significance. The illness time span varied from 1.6 to 16.3 years. In the trazodone group three patients left the protocol: Two due to sleepiness and one because of postural vertiginous sensation. These three patients were not included in the analysis performed. All patients took at least one of the following antiparkinsonian drugs: carbidopa + levodopa (250/25 $\mathrm{mg}$ ), amantadine (100 mg) and/or pramipexole (0.25-1g).

Table 1 shows the UPDRS variation and the corresponding $\mathrm{p}$ values for the moment-to-moment compari- sons, separating the groups with and without trazodone. To make things clearer the variation was analyzed from an initial time TO to an ending time T5. The initial average of the group G2 was of 33.1 (SD 19.7) rising to $37.1(\sigma=18.0)$ at the end. The initial average of the group $\mathrm{G} 1$ was 31.4 $(\sigma=11.3)$ ending in $25.9(\sigma=13.7)$. The result was stability in the group G2 and a slight decline in the group G1. The Wilcoxon test of 0.034 only showed results during the last period (T5), even so there was a reduction tendency. Figure shows the average value of the UPDRS by month. The variations in the Mann-Whitney test were 0.734 at the initial moment and 0.208 at the final moment. The variation in the comparison of the initial moment with the final moment was 0.005 providing statistical significance.

A moderate fall in the average of the UPDRS in the group Glwas observed, though no variation of this average in the group G2. The variation in the HAM-D from the initial moment until the final moment showed in the group $\mathrm{G} 2$ that the average varied from 11.4 ( $\mathrm{SD}=7.2$ ) to 10.2 $(S D=7.4)$. The $p$-value of the Wilcoxon test was 0.235 in the T5-T0 variation, with statistical significance. In the group $\mathrm{G} 1$ the initial average was $12.4(\mathrm{SD}=6.3)$ and final average $6.0(S D=4.6)$. The $p$-value of the Wilcoxon test was of 0.062 in variation T5-TO. The average of the HAM-D went up by 4 points in the group $\mathrm{G} 2$ and went down by 5.5 points in the group $\mathrm{G} 1$.

The groups at the initial moment and the final moment were analyzed, showing a fall on average of 12.4 at the initial moment to 6.0 at the final moment in the group G1. The $p$-value of the Wilcoxon test was 0.115 in the T5-T0 variation, demonstrating a tendency to drop. In the group G2 the patients at the cutting off point of ten points had remained unchanged in the points of the HAM-D until the

Table 2. Statistics of the HAM-D according to time.

\begin{tabular}{|c|c|c|c|c|c|c|c|c|c|c|c|}
\hline \multicolumn{12}{|c|}{ Without medication $(n=12)$} \\
\hline \multirow[b]{2}{*}{ Descriptive statistics } & \multicolumn{6}{|c|}{ HAM-D } & \multicolumn{5}{|c|}{ Initial evaluation (t0) } \\
\hline & to & $\mathrm{t} 1$ & t2 & t3 & t4 & t5 & t1-t0 & $\mathrm{t} 2-\mathrm{t0}$ & t3-to & t4-t0 & t5-to \\
\hline Average & 11.4 & 10.0 & 11.0 & 10.8 & 10.2 & 10.2 & -1.4 & -0.4 & -0.7 & -1.3 & -1.3 \\
\hline SD & 7.2 & 7.8 & 7.7 & 7.4 & 6.9 & 7.4 & 2.6 & 2.2 & 3.0 & 2.9 & 3.1 \\
\hline Medium & 11.5 & 7.0 & 11.0 & 10.0 & 10.0 & 9.5 & -0.5 & -0.5 & -2.0 & -2.0 & -2.0 \\
\hline \multicolumn{7}{|c|}{ P-value Wilcoxon test } & 0.083 & 0.486 & 0.398 & 0.218 & 0.235 \\
\hline \multicolumn{12}{|c|}{ With medication $(n=8)$} \\
\hline & \multicolumn{6}{|c|}{ HAM-D } & \multicolumn{5}{|c|}{ Initial evaluatiom (to) } \\
\hline Descriptive statistics & to & $\mathrm{t} 1$ & $\mathrm{t} 2$ & t3 & t4 & t5 & $\mathrm{t} 1-\mathrm{t0}$ & t2-t0 & t3-to & $\mathrm{t} 4-\mathrm{t0}$ & t5-t0 \\
\hline Average & 12.4 & 10.0 & 8.5 & 6.6 & 5.9 & 6.0 & -2.4 & -3.9 & -5.8 & -6.5 & -6.4 \\
\hline SD & 6.3 & 6.8 & 5.7 & 5.0 & 4.6 & 4.6 & 5.2 & 6.8 & 6.7 & 6.7 & 6.8 \\
\hline Medium & 14.0 & 8.5 & 7.5 & 5.0 & 4.0 & 4.0 & -1.5 & -2.0 & -3.5 & -6.0 & -6.0 \\
\hline \multicolumn{7}{|c|}{$\mathrm{p}$-value Wilcoxon test } & 0.248 & 0.104 & 0.034 & 0.045 & 0.062 \\
\hline
\end{tabular}

HAM-D: Hamilton Depression Rating Ssale; SD: standard deviation. 
Table 3. Spearman correlation coefficients for UPDRS and HAM-D.

\begin{tabular}{|c|c|c|c|c|c|c|}
\hline \multicolumn{7}{|c|}{$\mathrm{G} 2(\mathrm{n}=12)$} \\
\hline & & \multicolumn{3}{|c|}{ UPDRS } & \multicolumn{2}{|c|}{ HAM-D } \\
\hline \multicolumn{2}{|c|}{ UPDRS and HAM-D } & Initial (to) & Final $(\mathrm{t} 5)$ & Variation $(\Delta)$ & Initial (to) & Final (t5) \\
\hline \multirow[t]{2}{*}{ Final UPDRS } & correlation & 0.895 & 1 & & & \\
\hline & p-value & $<0.001$ & & & & \\
\hline \multirow[t]{2}{*}{$\triangle$ UPDRS } & correlation & -0.140 & 0.175 & 1 & & \\
\hline & p-value & 0.664 & 0.586 & & & \\
\hline \multirow[t]{2}{*}{ Initial HAM-D } & correlation & 0.748 & 0.695 & -0.041 & 1 & \\
\hline & p-value & 0.005 & 0.012 & 0.900 & & \\
\hline \multirow[t]{2}{*}{ Final HAM-D } & correlation & 0.867 & 0.839 & 0.158 & 0.881 & 1 \\
\hline & p-value & $<0.001$ & 0.001 & 0.623 & $<0.001$ & \\
\hline \multirow[t]{2}{*}{$\Delta$ HAM-D } & correlation & 0.430 & 0.349 & -0.069 & -0.016 & 0.358 \\
\hline & $\mathrm{p}$-value & 0.163 & 0.266 & 0.831 & 0.961 & 0.254 \\
\hline \multicolumn{7}{|c|}{ G1 (n=8) } \\
\hline & & \multicolumn{3}{|c|}{ UPDRS } & \multicolumn{2}{|c|}{ HAM-D } \\
\hline \multicolumn{2}{|c|}{ UPDRS and HAM-D } & Initial (to) & Final $(\mathrm{t} 5)$ & Variation $(\Delta)$ & Initial (to) & Final (t5) \\
\hline \multirow[t]{2}{*}{ Final UPDRS } & correlation & 0.946 & 1 & & & \\
\hline & p-value & $<0.001$ & & & & \\
\hline \multirow[t]{2}{*}{$\triangle$ UPDRS } & correlation & 0.323 & 0.530 & 1 & & \\
\hline & p-value & 0.435 & 0.177 & & & \\
\hline \multirow[t]{2}{*}{ Initial HAM-D } & correlation & 0.479 & 0.452 & -0.398 & 1 & \\
\hline & p-value & 0.230 & 0.261 & 0.329 & & \\
\hline \multirow[t]{2}{*}{ Final HAM-D } & correlation & 0.166 & 0.238 & 0.295 & 0.045 & 1 \\
\hline & $\mathrm{p}$-value & 0.694 & 0.571 & 0.477 & 0.916 & \\
\hline \multirow[t]{2}{*}{$\Delta$ HAM-D } & correlation & 0.740 & 0.799 & 0.744 & -0.744 & 0.423 \\
\hline & p-value & 0.036 & 0.017 & 0.034 & 0.034 & 0.297 \\
\hline
\end{tabular}

UPDRS: Unified Parkinson's Disease Rating Scale Score; HAM-D: Hamilton Depression Rating Scale.

end. In the medicated patients only one, of a total of six, remained unchanged

In Table 2, the group at the initial moment and the final moment is analyzed, showing a fall on average of 12.4 at the initial moment to 6.0 at the final moment in the group G1. The p-value of the Wilcoxon test was 0.115 in the T5-TO variation, demonstrating a tendency to drop. In the group G2 the patients at the cutting off point of ten points had remained unchanged in the points of the HAM-D until the end. In the medicated patients only one, of a total of six, remained unchanged. Table 3 shows the Spearman correlation coefficients on the variables of the HAM-D and the UPDRS scales. The UPDRS finding of 0,895 is highly correlated and significant as it is so close to 1.

\section{DISCUSSION}

From the existing literature, reporting on both in vivo and postmortem data in animal models and in humans, it is apparent that the serotonergic neurotransmitter system is involved in the pathophysiology of PD. The experimental evidence supporting the role of serotonin in motor control was firstly found in $1993^{12}$. Prospective survey suggested that depression associates psychomotor disturbances to some type of dopaminergic dysfunction ${ }^{13-15}$.

A strong correlation between the depression severity and degree of motor dysfunction was demonstrated in $\mathrm{PD}^{16}$. The authors speculated that the reduced serotonin levels in PD could be related to the reduced motor activity in depressed patients with PD, which is observed especially when these are compared to the non-depressed patients. They also described an association of depression with the severity of bradykinesia and axial rigidity.

Other studies also associated motor function and depressive symptoms in $\mathrm{PD}^{14,17}$. In a revision of these studies Di Giovanni et al. ${ }^{8}$ reported that the exposition of striatum and nucleus accumbens to serotonin causes an increase in dopamine release. After checking that drugs acting on the receptors 5-HT2c can diminish the levodopa-induced diskynesias, concluded that these receptors participate in the functions of the basal ganglia and the pathophysiology of parkinsonism.

In animal models of PD serotonergic research has mainly focused on the $5-\mathrm{HT} 1$ and $5-\mathrm{HT} 2$ receptor subtype. According to Scholtissen and cols. ${ }^{18}$, the most rele- 
vant aspects of the serotonin-dopamine relationship are the following: (A) The 5-HT2a receptor is excitatory for dopamine release, while $5-\mathrm{HT} 2 \mathrm{c}$ is inhibitory; (B) the progressive degeneration of the dopaminergic neurons causes the dopamine synthesis to occur in serotoninergic terminals; (C) Neuroimagings show reduction of serotonin in some cortical and subcortical areas in PD; (D) there is a reduction in 5-HT2a receptors density in the premotorcortex contralaterally to the side of motor symptoms onset in PD. The compensatory reduction of the serotonin secondary to the dopaminergic neuronal loss may contribute to the improvement of the motor function, but this may increase the risk of depression significantly.

Two previous reports ${ }^{19,20}$ showed that trazodone may improve tremor in PD. However, these studies were not randomized, not blind, and patients were not submitted to the HAM-D or UPDRS scales. In our study the choice of not doing a double-blind study or not treating the control group with placebo, possibly restricts the significance of the finding. However, studies involving placebo in PD might generate conflicting results. In PD dopaminergic activation of pathways mediating reward may be responsible for a positive placebo response in up to $50 \%$ of patients ${ }^{21}$. Same results have been seen in depression, where placebo partially reproduces selective reuptake inhibitor-mediated brain activation.

Trazodone is a serotonin reuptake inhibitor with specific antagonistic action at $5-\mathrm{HT} 2 \mathrm{a} / 2 \mathrm{c}$ receptors. A dopaminergic burst while the system suffers an antagonist action is apparently a paradox. However, Balsara et al. ${ }^{10}$ signaled that the antagonistic action of trazodone at receptors $5-\mathrm{HT} 2 \mathrm{c}$ clearly predominates. The trazodone dopaminergic action at $5-\mathrm{HT} 2 \mathrm{c}$ receptors is observed with doses varying from 5 to $20 \mathrm{mg} / \mathrm{kg} /$ day. Larger doses determining contrary effects may be related to lower tolerance. This could also occur with antidepressants because of desensitization of serotoninergic autoreceptors at neurons in the raphei nucleus ${ }^{22}$.

Di Matteo et al. ${ }^{23}$ reported that the disinhibition of the mesocorticolimbic function induced by $5-\mathrm{HT} 2 \mathrm{c}$ receptors antagonism may treat psychotic symptoms in PD, since second generation neuroleptics produce fewer extrapyramidal effects and have an inverse $5-\mathrm{HT} 2 \mathrm{c}$ agonist action. The antidepressive performance of the receptors $5-\mathrm{HT} 2 \mathrm{c}$ could therefore serve as a model for the treatment of depression in PD. Based on the principle that the activation of 5-HT2c receptors increases the activity in the substantia nigra, it is possible that the stimulation of these receptors contributes to an increase in basal ganglia output which would favour parkinsonian symptoms. The expression of $5-\mathrm{HT} 2 \mathrm{c}$ receptors in the substantia nigra pars reticulata and in the medial pallidal complex supports this hypothesis ${ }^{24}$. Moreover, $5-\mathrm{HT} 2 \mathrm{c}$ receptors binding was in- creased in a model of parkinsonism developed in rats ${ }^{25}$, as well as in parkinsonian patients ${ }^{26}$.

In an open study ${ }^{27}$, where an average dose of nefazodone for a period of four months on three depressive patients with PD, was used, there were improvements in the motor symptoms submitted previously to fluoxetine. The results showed reduction of tremor in the three patients, and a discrete improvement, at the beginning and in the development of gait in another two.

This comment would be repeated in the following year by Avila et al. ${ }^{28}$, who compared motor improvement following nefazodone in nine depressed parkinsonian patients, with a fluoxetine treated control. Motor improvement following nefazodone was reported in parkinsonian patients and not in fluoxetine treated group. According to Avila and colleagues, blocking $5-\mathrm{HT} 2$ receptors promotes dopamine release and a subsequent reduction of $D 2$ receptor blockade, resulting in a reduction of extrapyramidal symptoms.

Experimental studies suggest a primary relationship and the importance of dopaminergic mechanisms in PD and depression. Thus, treatment with dopamine agonists promises to reduce motor complications as well as depressive symptoms, avoiding multiple drug interactions as well as possible antidepressant medication side effects ${ }^{29}$. There are case reports and echocardiographic studies suggesting that the ergot-derived dopamine agonists, pergolide and cabergoline, increase the relative risk of cardiac-valve regurgitation ${ }^{30}$. No cases were attributed to ropinirole or pramipexole, but like antidepressants these non-ergoline substances most commonly causes nausea and sleep disturbances. Also, drug-induced psychosis may complicate the course and management of PD and are associated with dopamine agonists.

Several reports show that non-5-HT2c antagonistic SSRIs may abruptly unleash parkinsonism. However, PD evolves slowly over many years. There is no report on the motor evolution of PD patients under these drugs for a period longer than seven months. The chronic use of SSRls with this type of action may perhaps lead to a worsening of the motor function in this context.

Based on available data, trazodone significantly improved motor symptoms only in depressed patients. This result also favors the hypothesis that depressed PD patients may gain a benefit in the motor symptoms when treated by antidepressants, and that this effect may be related, at least in part, to the inhibition of the $5-\mathrm{HT} 2 \mathrm{c}$ receptor.

This review demonstrates the overall benefits of continuation- and maintenance-phase treatment of depression in PD with antidepressants and emphasizes the need for additional studies of comparative differences among drugs. Other second-generation antidepressants 5-HT2C antagonists could also have similar effects. 


\section{REFERENCES}

1. Giupponi G, Pycha R, Erfurrth A, Hausmann A, Conca A. Depressive symptoms and the idiopathic Parkinson's syndrome (IPS): a review. Neuropsychiatr 2008;22:71-82.

2. Prado RC, Barbosa ER. Depression in Parkinson's disease. Arq Neuropsiquiatr 2005;63:766-771.

3. Tumas V, Rodrigues GG, Ricioppo F, Tarsis LA, Crippa JAS. The accuracy of diagnosis of major depression in patients with Parkinson's disease: a comparative study among the UPDRS, the geriatric depression scale and the Beck depression inventory. Arq Neuropsiquiatr 2008;63:152-156.

4. Sigwald J, Bouttier CI, Raymondeaud M, Marquez Mlle, Gal J.-C. Étude de l'action sur l'akinésie parkinsonienne de deux derives de l'iminodibenzyle: imipramine ou 8307 RP. Presse Medical 1959;67:1697-1698.

5. Chung TH, Deane KH, Ghazi-Noori S, Rickards H, Clarke CE. Systematic review of antidepressant therapies in Parkinson's disease. Parkinsonism Relat Disord 2003;10:59-65.

6. Pimentel MM, Moura KC, Abdalla CB, et al. A study of LKRR2 mutations in Brazil. Neurosci Lett 2008; 433:17-21.

7. Le Pen G, Sonnier L, Hartmann A, et al. Progressive loss of dopaminergic neurons in the ventral midbrain of adult mice heterozygote for Engrailed1: a new genetic model for Parkinson's disease? Parkinson Relat Disord 2008;14:107-111.

8. Di Giovanni G, Di Matteo V, Pierucci M, Benigno A, Esposito E. Central serotonin 2C: From physiology to pathology. Curr Top Med Chem 2006;6:1909-1925.

9. Lucas G, De Deurwaerdere P, Caccia S, Umberto S. The effect of serotonergic agents on haloperidol-induced striatal dopamine release in vivo: opposite role of 5-HT(2A) and 5- $\mathrm{HT}(2 \mathrm{C})$ receptor subtypes and significance of the haloperidol dose used. Neuropharmacology 2000;39:1053-1063.

10. Balsara JJ, Jahdav SA, Gaonkar RK, Gaikwad RV, Jahdav JH. Effects of the antidepressant trazodone, a 5-HT2a/2c antagonist, on dopamine-dependent behavior in rats. Psychopharmacology 2005;179:597-605.

11. Calne DB, Snow BJ, Lee C. Criteria for diagnosing Parkinson's disease. Ann Neurol 1992;32:125-127.

12. Jacobs BL, Fornal CA. 5-HT and motor control: a hypothesis. Trends Neurosci 1972;16:346-352.

13. Sachdev P, Aniss AM. Slowness of movement in melancholic depression. Biol Psychiatry 1994;35:253-262.

14. Kuhn W, Heye N, Muller T, et al. The motor performance test series in Parkinson's disease is influenced by depression. J Neural Transm 1996;103:349-354.

15. Malhi GS, Berk M. Does dopamine dysfunction drive depression? Acta Psychiatr Scand 2007;433:116-124.

16. Papapetropoulos S, Ellul J, Argyriou AA, Chroni E, Lekka NP.
The effect of depression on motor function and disease severity of Parkinson's disease. Clin Neurol Neurosurg 2006;108:465-469.

17. Mayeux R, Stern Y, Cote L, Williams JBW. Altered serotonin metabolism in depressed patients with Parkinson's disease. Neurology 1984;34:642-646.

18. Scholtissen B, Verley FRJ, Steinbush HWM, Leetjens AFG. Serotonergic mechanisms in Parkinson's disease: opposing results from preclinical and clinical data. J Neural Transm 2006;113:59-73.

19. Mastrosimone F, Coluci d'Amato C, De Angelis G, Iaccarino C, Giordano L, Armo E. Personal experience with a combination of drugs in subjects with dopa resistant Parkinson's disease. J Med 1980;11:377-383.

20. Piccinin GL, Piccirilli M, Agostini L. La terapia del Parkinson com l'associazione L-dopa (più carbidopa) e trazodone. Cl Terap 1981;96:621-626.

21. Diederich NJ, Goetz CG. The placebo treatment in neurosciences: new insights from clinical and neuroimaging studies. Neurology 2008;71:677-684.

22. Blier P, deMontigny C, Chaput Y. Modification of the serotonin system by antidepressant treatment: implications for the response in major depression. J Clin Psychopharmacol 1987;7:24-35.

23. Di Matteo V, Cacchio M, Di Giulio C, Esposito E. Role of serotonin $(2 \mathrm{C})$ receptors in the control of brain dopaminergic function. Pharmacol Biochem Behav 2002;71:727-734.

24. Abramowski D, Rigo M, Due D, Hoyer D, Staunfebiel M. Localization of 5- hydroxytryptamine 2 c receptor protein in human and rat brain using specific antisera. Neuropharmacology 1995;34:1635-1645.

25. Radja F, Descarries L, Dewar KM, Reader TA. Serotonin 5-HT1 and 5-HT2 receptors in adult rat brain after destruction of nigrostratal dopamine neurons: a quantitative autoradiographic study. Brain Res 1993;606:273-285.

26. Fox SH, Brotchie JM. 5-HT2c receptor binding is increased in the substantia nigra pars reticulata in Parkinson's disease. Mov Disord 2000;15:1064-1069.

27. Werneck ALS, Gonçalves AFS. Nefazodona no parkinsonismo secundário à fluoxetina. Arq Neuropsiquiatr 2002;60:1:114.

28. Avila A, Cardona X, Martin-Baranera M, Maho P, Sastre F, Bello J. Does nefazodone improve both depression and Parkinson's disease? A pilot randomized trial. J Clin Psychopharmacol 2003;23:509-513.

29. Lemke MR, Brecht HM, Koester J, Reichmann H. Effects of the dopamine agonist pramipexole on depression, anhedonia and motor functioning in Parkinson's disease. J Neurol Sci 2006;25:266-270.

30. Zanettini R, Antonini A, Gatto G, Gentile R, Tesei S, Pezzoli G. Valvular heart disease and the use of dopamine agonists for Parkinson's disease. N Engl J Med 2007; 356:39-46. 